\title{
Sob a espada de Dâmocles: Os militares no Brasil e a democracia tutelada
}

\author{
Aline Prado Atassio ${ }^{1}$, Roque Pinto ${ }^{2}$ e Sócrates Jacobo Moquete Guzmán ${ }^{3}$
}

Resumo: Durante os anos pós-ditadura militar os militares atuaram no Brasil sem grandes alardes, exercendo um poder silencioso, porém incisivo em assuntos militares e civis. Este texto, realizado através de uma vasta revisão bibliográfica, busca analisar essa atuação militar na história recente do Brasil e os consequências para a atualidade. A hipótese central é a de que os militares configurariam uma verdadeira espada de Dâmocles, suspensa pelo fio de rabo de cavalo (a volição de políticos e magistrados que têm sua própria pauta ética e política), a pender sobre a cabeça daqueles dos que representam a institucionalidade do Brasil. Desta forma, observa-se que no lapso temporal de 1985 a 2018, que vai do fim da ditadura de 64 até a eleição de Bolsonaro que inaugurará um novo momento marcado por ataques sistemáticos aos pilares democráticos, institucionais e civilizacionais, e pelo aparelhamento sem precedentes do Estado pelos militares -, a caserna atuou como um verdadeiro tutor da democracia (e dos governos civis) e nos raros momentos em que foi confrontada operou abertamente para derrubar o poder constituído, reforçando a ideia de que não só os militares se colocam como os senhores da república, outorgando a si mesmos o direito de sustá-la, como também - contrariando o senso comum - jamais deixaram de fazer política, a seu modo.

\section{Introdução}

Atribui-se ao maestro brasileiro Tom Jobim a frase "o Brasil não é para principiantes", referindo-se às agudas contradições da sociedade brasileira e aos problemas estruturais que se acumulam ao longo da sua história. O Brasil, único Império das Américas no período posterior à Grandes Navegações (entre 1822 e 1889), foi também o último país americano a abolir formalmente a escravidão, por decreto imperial de 13 de maio de 1888. E teve sua primeira universidade apenas em 1912, já que os colonizadores portugueses proibiam a criação de unidades de ensino superior na então colônia, enquanto que a fundação da

\footnotetext{
${ }^{1}$ Doutora em Ciências Sociais. Especialista em Estudos Militares. Membro do LAHISP (Laboratório de História do Poder e das Ideologias - UFF). Professora substituta na Universidade Federal de Alagoas (UFAL).

2 Doctor Europaeus em Antropologia pela Universidad de La Laguna, Espanha. Professor Titular de Antropologia na Universidade Estadual de Santa Cruz,

${ }^{3}$ Graduado e Mestrado em Economia. Doutor em Ciência Política pela Universidade Federal do Rio Grande do Sul. É docente efetivo na Universidade Estadual de Santa Cruz, Ilhéus-BA.
} 
primeira universidade das Américas se deu na República Dominicana, no ano de 1538, seguida da universidade de San Marcos no Peru, no ano de 1551.

É no encadeamento de uma série de contradições inerentes à própria compleição social, cultural, econômica, histórica e simbólica do país - incluindo um dos maiores índices de desigualdade do mundo, a quarta maior população carcerária e uma das maiores taxas de homicídio do planeta que se dá uma complexa relação entre o mundo civil e os militares no Brasil.

Mesmo porque a república brasileira surge de um golpe militar deflagrado contra o Imperador D. Pedro - II (CARVALHO, 2005), o que faz com que os militares enxerguem a si mesmos como verdadeiros donos da república, sendo o comando civil do país uma concessão militar a título precário, que poderia ser sustado a qualquer tempo caso "saia dos trilhos", conforme os relativos critérios militares de liberdade e democracia (ATASSIO, 2007).

Nesta perspectiva, os militares se configurariam como uma verdadeira espada de Dâmocles, suspensa pelo fio de rabo de cavalo (a volição de políticos e magistrados que têm sua própria pauta ética e política), a pender sobre a cabeça daqueles dos que representam a institucionalidade do Brasil. E é neste sentido que o texto pretende pontuar o cerco permanente da instituição militar ao poder constituído no período democrático (1985-2018), demonstrando que, mesmo buscando refratar uma imagem pública de distanciamento, equidistância e comedimento, a caserna nunca esteve afastada da vida política nacional.

Esse artigo, finalizado em inícios de agosto de 2021, ganha relevância pela crise entre os poderes Executivo e Judiciário, provocada pela truculência do Presidente Bolsonaro em seu ataque às instituições democráticas. Principalmente, as acusações, sem provas, ao sistema eleitoral, assim como as agressões aos juízes do Supremo Tribunal Federal e ameaças de golpe de Estado militar, inclusive tratadas abertamente nestes termos pela mídia mainstream. Embora esses episódios específicos não sejam objeto do artigo, as questões aqui tratadas podem se constituir em base para compreensão da conjuntura, caracterizada pela citada crise, especialmente considerando a organicidade entre o governo Bolsonaro e os militares e sendo ele próprio uma expressão fortemente histriônica do autoritarismo brasileiro. 


\section{Brasil: um turbilhão político e econômico}

O dia primeiro de abril de 1964 foi um importante divisor de águas da história brasileira. Não apenas pela sucessão de eventos que foram desencadeados posteriormente, como também foi a culminância de um movimento na sociedade que se desenrolava desde que o país se tornara um Império. O primeiro e único das Américas desde as Grandes Navegações.

Naquele dia o presidente João Goulart perdeu efetivamente o controle do exército e não conseguiu impor uma reação legalista aos militares golpistas que vinham conspirando há meses juntamente com segmentos civis, como parte do empresariado, políticos e mídia corporativa. No dia seguinte se efetivou a derrubada do governo de centro-esquerda e uma junta militar se autodeclarou mandatária suprema do país, que sob o pretexto de garantir a democracia impôs uma ditadura que perdurou por vinte anos no país.

O golpe de 64 se deu dentro de um plano geopolítico mais amplo, fortemente marcado pela ingerência dos Estados Unidos na América Latina, que deu suporte de toda natureza às ditaduras militares na região, nas décadas de 1960 e 1970. A a política repressiva na região foi sistematizada com a Operação Condor, que deu organicidade e sinergia às ditaduras da Argentina, da Bolívia, do Brasil, do Chile, do Paraguai e do Uruguai, criando uma rede internacional de terror de Estado cujos partícipes se retroalimentavam mutuamente. Especialmente no contexto brasileiro, os Estados Unidos apoiaram o golpe de estado através da Operação Brother Sam, por intermédio do seu embaixador Lincoln Gordon (PARKER, 2014).

Nos vinte anos seguintes, no período de 1964 a 1984, o Brasil viveu o que os historiadores chamam de "anos de chumbo", sendo o país governado por militares sob uma forte tutela estadunidense. Progressivamente o regime militar foi recrudescendo seus instrumentos repressivos ao tempo em que avançava contra os direitos constitucionais até suprimi-los por completo ao decretar o Ato Institucional número 5 (Al-5). Como consequência, as esquerdas intensificam ações pela via armada, com a eclosão de centenas de organizações de guerrilha, tanto urbanas quanto no interior do país. Credita-se ao período de fins de 1968 
a março de 1974 a fase mais repressiva da ditadura, coincidente com a presidência do General Emílio Garrastazu Médici.

Sob a gestão Médici, ao mesmo tempo em que o regime político endurecia cada vez mais, forjava-se uma forte campanha nacionalista nos meios de comunicação, usando massivamente o slogan "Brasil, ame-o ou deixe-o". À euforia ufanista se seguia o chamado "milagre econômico" com a execução do Plano Nacional de Desenvolvimento, período em que o PIB nacional crescia a uma taxa de aproximadamente $10 \%$ ao ano, inclusive com a diversificação das atividades produtivas e a emergência de uma nova classe média urbana, enquanto que as desigualdades econômicas eram aprofundadas, especialmente entre as populações urbana e rural (CANO, 2011).

A esse período se deve um processo de endividamento público exponencial, com a dívida externa saltando de US\$1,5 bilhões em 1964 para US $\$ 14$ bilhões em 1970, e atingindo, em 1985, no final do período militar, US\$ 90 bilhões. Esse montante custeou uma série de obras chamadas "faraônicas", como a Ponte Rio-Niterói, a Rodovia Transamazônica (hoje intrafegável em alguns trechos) e grandes usinas hidrelétricas, como Tucuruí e Itaipu. Era a chamada fase do "Brasil Grande" e do "Milagre Brasileiro" (LOPES, 1998).

Com o recrudescimento da ditadura militar, aumenta também a pressão pela eliminação do inimigo interno. Esse é um conceito absolutamente inviável dentro de uma democracia. De acordo com Chatal Mouffe (1996), é prerrogativa para a existência do regime democrático o convívio com a pluralidade. A diversidade é característica própria, nuclear da democracia.

Mouffe entende que o pensamento liberal, que ganhava cada vez mais força no mundo nas décadas de 1960 e 1970, é incapaz de compreender o significado do "político", em seu caráter antagônico, conflituoso, decorrente da natureza da práxis democrática. A autora explica que se mostra impossível a ausência de diferenças no mundo e que o desafio é justamente a manutenção de uma democracia pluralista. Sendo assim, a democracia só é possível se o oponente político é tratado como adversário e não como inimigo.

Num regime "total", como anotam os especialistas, os espaços (temporais e sociais) dedicados ao tempo livre são igualmente diligenciados. No contexto brasileiro, nesse momento, o próprio futebol, por exemplo, não só fora usado 
como instrumento de propaganda política como inclusive era tratado como assunto de Estado: a comissão técnica e a diretoria da Confederação Brasileira de Desportos (CBD), que no final da década de 1970 se tornaria Confederação Brasileira de Futebol, eram regiamente geridas por militares.

Em 1974, o presidente da CBD era o Almirante Heleno Nunes e o preparador físico da seleção brasileira e depois seu treinador no Mundial de 1978, na Argentina, era o capitão de Artilharia do Exército Cláudio Coutinho. A esse respeito, em relação aos imbricamentos entre as ditaduras sul-americanas e o futebol, o escritor uruguaio Eduardo Galeano $(2004,158)$ diz que:

"En pleno carnaval de la victoria del 70, el general Médici, dictador del Brasil, regaló dinero a los jugadores, posó para los fotógrafos con el trofeo en las manos y hasta cabeceó una pelota ante las cámaras. La marcha compuesta para la selección, Pra Frente Brasil, se convirtió en la música oficial del gobierno, mientras la imagen de Pelé volando sobre la hierba ilustraba, en la televisión, los avisos que proclamaban: Ya nadie detiene al Brasil. Cuando Argentina ganó el Mundial del 78, el general Videla utilizó con idénticos propósitos la imagen de Kempes imparable como un huracán.

El fútbol es la patria, el poder es el fútbol: Yo soy la patria, decían esas dictaduras militares.

Mientras tanto, el general Pinochet, mandamás de Chile, se hizo presidente del club Colo-Colo, el más popular del país, y el general García Meza, que se había apoderado de Bolivia, se hizo presidente del Wilstermann, un club con hinchada numerosa y fervorosa.

El fútbol es el pueblo, el poder es el fútbol: Yo soy el pueblo, decían esas dictaduras militares."

Mas, em que pese o esporte e a arena artística e midiática acionadas para funcionar como o "ópio do povo" a serviço da manutenção do regime, o descontentamento popular começava a dar sinais mais evidentes. No campo econômico, ao final do governo Médici, em 1974, as taxas de crescimento começavam a cair, em parte em função da Crise do Petróleo de 1973 e em parte devido às contradições dentro da própria condução da política econômica nacional.

A partir de 1974, com o governo do General Ernesto Geisel, pari pasu ao endividamento público e o aumento da inflação, dá-se uma abertura política gradual, sendo revogado o Al-5, em 1978. No ano seguinte foi indicado como presidente o general João Baptista Figueiredo, num período marcado por uma queda acentuada do PIB e aumento da dívida externa e da inflação e, no plano político, pela anistia e a consequente reintegração dos direitos civis aos cidadãos 
brasileiros.

Em 15 de janeiro de 1985 o país assiste à eleição indireta de Tancredo Neves, seu primeiro presidente civil depois de 20 anos de regime militar. Contudo, Tancredo não chega a assumir o cargo. Na véspera do dia da posse é internado em circunstâncias pouco explicadas, vindo a falecer poucos meses depois.

Assume a presidência o vice, José Sarney, cujo mandado foi marcado, no plano político, pela consolidação da vida democrática do país, com a realização de eleições diretas para prefeito em 1985 (as primeiras em vinte anos) e, no ano seguinte, para a Assembleia Nacional Constituinte. Extinguiu-se a censura prévia nos meios de comunicação e foram legalizados todos os partidos políticos, até então clandestinos.

Como resultado de uma aguda crise econômica, vivia-se uma hiperinflação sem precedentes, que foi enfrentada por uma série de medidas "heterodoxas". A primeira e mais impactante delas foi o Plano Cruzado, em 1986, que consistiu na mudança da moeda (de cruzeiro para cruzado, na proporção de 1/1.000, isto é, um cruzado equivalia a 1.000 cruzeiros), a suspensão da correção monetária, o congelamento geral de preços por 12 meses e a criação da Escala Móvel de Salários ou "gatilho salarial", um reajuste automático de salários sempre que a inflação acumulada atingisse o patamar de $20 \%$ ao mês.

Inicialmente os consumidores passaram a fiscalizar os preços e denunciar aumentos irregulares, mas seu resultado a médio prazo foi o desabastecimento de alimentos e a cobrança de ágio em praticamente todos os bens de consumo, gerando filas intermináveis nos supermercados, limitação de compra de produtos por pessoa e um poderoso mercado negro que convertia virtualmente todos os brasileiros em contraventores.

Vendo-se incapaz de sustentar política e economicamente o Plano Cruzado, o governo lançou o Plano Cruzado II, juntamente com a decretação unilateral da suspensão do pagamento da dívida externa (moratória) em 1987. Com o fracasso do Plano Cruzado, Bresser Pereira assume o Ministério da Fazenda, lançando o Plano Bresser. Em dezembro desse mesmo ano a inflação atinge o índice de 366\%. Em janeiro do ano seguinte o ministro se demite. Em 1988, dez anos após a revogação do Al-5, é promulgada uma nova constituição 
Universidade Federal Fluminense

Instituto de Estudos Estratégicos

no Brasil.

Em 1989 é lançado o Plano Verão, baseado no congelamento de preços e salários e se cria uma nova moeda, o cruzado novo, cuja unidade equivalia a 1.000 cruzados, e foi inicialmente atrelada à paridade com o dólar estadunidense. Sarney deixa seu mandato com uma inflação de mais de $2.750 \%$ ao ano.

Neste ano ocorrem as primeiras eleições diretas para presidente desde 0 golpe militar de 1964. Foram para o segundo turno das eleições presidenciais os candidatos Luiz Inácio Lula da Silva e Fernando Collor de Mello, sagrando-se esse último o vencedor do pleito, com apoio total dos meios de comunicação de massa e com um discurso populista e alinhado a um liberalismo sem ressalvas, que relacionava Lula com o "comunismo decadente" e ele próprio como o "governador dos descamisados" e perseguidor de funcionários públicos de altos salários (ou "caçador marajás", como se dizia na época).

No dia seguinte à posse, o presidente Collor anunciou um pacote econômico de grande impacto. O Plano Collor (cujo nome oficial era Plano Brasil Novo) decretava a volta do cruzeiro como moeda, um inacreditável confisco de todos os depósitos bancários no país superiores a cinquenta mil cruzeiros por um prazo de dezoito meses, alteração no cálculo da correção monetária e das aplicações financeiras, criação de um programa de privatização de empresas públicas, demissão de funcionários públicos e o congelamento de preços e salários.

Aprofundou-se a recessão econômica, agora agigantada pela escassez de moeda circulante e aumento exponencial do desemprego, com a extinção, somente em 1990, de mais de 920 mil postos de trabalho, diante de uma inflação de $1200 \%$ ao ano (CANO, 2008).

Seguiu-se à desregulamentação financeira a abertura da economia brasileira ao mercado externo (com a importação massiva e sem precedentes de todo tipo de produto, de automóveis russos a cervejas sul-africanas), o que impactou fortemente a indústria nacional, bruscamente submetida a uma competição com parques industriais mais modernos e que tinham custos financeiros, operacionais e logísticos bem menores do que os brasileiros, agravando ainda mais os efeitos negativos do plano econômico. Ainda foram 
lançados, até o ano de 1991, os planos Collor Il e o Plano Marcílio (CANO, 2008).

No campo político, o marco mais importante do governo Collor foi a deflagração de um dispositivo jurídico-legal que até então só existia como objeto de apreciação teórica: o Impeachment (DINIZ, 1997). Em junho de 1991 o próprio irmão do presidente o denunciara em alguns veículos midiáticos de circulação nacional como sendo membro de uma imbricada teia de corrupção engendrada pelo empresário Paulo César Farias para lavagem de dinheiro em paraísos fiscais, com tentáculos inclusive com as máfias europeias, num episódio que ficou conhecido como "Esquema PC". A Polícia Federal começou a investigar as denúncias e o Congresso Nacional instaurou uma Comissão Parlamentar de Inquérito (CPI) em busca de evidências materiais sobre as acusações.

O presidente foi à televisão rechaçar as acusações, chamando-as de "intenções golpistas" e conclama a população a sair de casa vestida de verde e amarelo em seu apoio. No entanto milhares de estudantes vão às ruas em passeatas cada vez maiores vestidos de negro e com os rostos pintados - sendo chamados de "cara-pintadas" - e exigindo a saída imediata do mandatário, configurando-se como a maior mobilização popular do país jamais vista até então.

O relatório final da apuração concluiu que o presidente da República e seus familiares tiveram despesas pessoais pagas ilegalmente pelo "Esquema PC". Numa votação aberta, transmitida ao vivo pela televisão, com recorde de audiência, a Câmara dos Deputados aprovou o pedido de abertura do processo de Impeachment contra o presidente Fernando Collor de Mello, fato insigne por ser a primeira vez em que um presidente seria destituído do seu cargo mediante este recurso jurídico-legal.

É empossado o vice-presidente Itamar Franco, com o país imerso numa aguda crise econômica, com a inflação atingindo $1100 \%$ ao ano em 1992, e alcançado quase $6000 \%$ no ano seguinte (DINIZ, 1997). Depois de várias trocas de ministros da economia assume a pasta da fazenda Fernando Henrique Cardoso, que lança o Plano Real em 1994, baseado em cinco pilares vitais: ajuste fiscal, desindexação da economia, restrição da política monetária, redução das tarifas de importação e câmbio artificialmente valorizado.

E, posteriormente, ocorreu a mudança da moeda para Real, dentro de um 
processo transitório em que as unidades monetárias anteriores tinham seu valor corrigido diariamente por um indexador chamado Unidade Real de Valor (URV), até a emissão definitiva da nova moeda, o Real (CARVALHO et al, 2007).

Fernando Henrique Cardoso se elege presidente em 1994, vencendo o pleito já no primeiro turno, então considerado candidato imbatível por ter coordenado um plano de estabilidade econômica aparentemente definitivo. De fato, debelou-se a hiperinflação, mas, com o câmbio supervalorizado, viu-se a entrada maciça de produtos importados que vieram a dominar grandes fatias do mercado interno, com a consequente falência de centenas de indústrias nacionais e milhares de demissões de trabalhadores.

Com uma balança comercial altamente desfavorável e com o controle da inflação mantido ao custo do ingresso de capital externo de alta volatilidade (hotmoney) e de grande endividamento externo, durante a vigência do Plano Real o país, que estava altamente vulnerável aos mercados internacionais, sofreu o impacto de várias crises econômicas, como a mexicana de 1994, a asiática de 1997 e a russa de 1998 (CARVALHO et al, 2007).

Apresentando-se como o único candidato capaz de comandar o país "em tempos de crises globais", Cardoso se reelege em 1998. No seu segundo mandato o país ainda viria a sofrer a desvalorização cambial de 1999 e a crise argentina de 2001, dada a extrema vulnerabilidade das contas públicas e 0 crescimento sem precedentes da dívida externa. Os custos da contenção da inflação foram a estagnação econômica, a privatização e precarização dos serviços públicos, a recessão e o aumento exponencial da dívida externa (CARVALHO et al, 2007).

Ao final do mandato FHC, em 2002, o PIB teve um crescimento de $2,41 \%$ (BRASIL, 2019); a dívida pública brasileira, que representava 29,9\% do PIB em 1995 (início do seu primeiro mandato), atingia a marca de 56,5\% do PIB (R\$ 881 bilhões), de acordo com os dados do Banco Central do Brasil (BRASIL, 2019). A renda média do trabalhador na grande São Paulo (corrigida em reais) caiu de $R \$$ 1.127 em 1995 para R\$ 955 em 2001 (BRASIL, 2019a); o salário mínimo real aumentou em 42,06\% de 1995-2002 (BRASIL, 2019a); o número de brasileiros abaixo da linha da pobreza diminui de 13\% em 1995 para 10,3\% em 2002; entre 1994 e 2001 o desemprego nas dez regiões metropolitanas do país aumentou 
da faixa de 824.000 para 1.253.000 (BRASIL, 2019a). E de 1996 a 2002 o PIB per capita teve uma variação positiva de 0,72\% (BRASIL, 2019a). A relação Dívida Externa x PIB, que em 1995 era de 19,9\%, em 2002 saltara para 41,8\% (BRASIL, 2019).

$\mathrm{O}$ valor de mercado das empresas ao final do governo $\mathrm{FHC}$ alcançou 24,95\% de capitalização (BANCO MUNDIAL, 2018). O serviço da dívida total (em \% de exportações de produtos, serviços e renda primária) soma das amortizações do principal e os juros efetivamente pagos em moeda local ou estrangeira, bens ou serviços sobre a dívida de longo prazo, juros pagos sobre a dívida de curto prazo e amortizações (recompras e encargos) ao FMI se elevou de 38,56\% em 1995 para 72,04\% em 2002 (BANCO MUNDIAL, 2018). A taxa de Investimentos ficou estável representando 17,29\% do PIB em 1995 para 17,44\% em 2002 (BANCO MUNDIAL, 2018).

Especialmente nos decênios entre 1960 e 2000 registrou-se no contexto brasileiro uma política econômica errática, com uma série de sobressaltos e turbulências nos campos político e econômico, repercutindo sobre a poupança e o crédito familiar e/ou individual (BARROS DE CASTRO; SOUZA, 1985; CANO, 2008; GONÇALVES, 2013).

No ano de 2002 Luiz Inácio Lula da Silva disputa a eleição presidencial novamente (fora candidato em todos os pleitos desde a redemocratização do país: 1989, 1994, 1998, 2002 e 2006). Dessa vez, com uma campanha moderada e conciliadora, chega ao Palácio do Planalto com 61,27\% dos votos válidos (SINGER, A., 2010).

Sua política econômica foi marcada por um misto de continuísmo em alguns setores - como o ajuste fiscal e a manutenção do superávit primário, reduzindo assim a capacidade de investimento do Estado; a autonomia do Banco Central em relação ao Poder Executivo; o controle inflacionário (CARVALHO et al, 2007) e a concessão de compensações pecuniárias a famílias de baixa renda - e algumas mudanças em áreas estratégicas (demasiado lentas e tímidas segundo as facções políticas à esquerda), especialmente no fomento ao mercado de consumo interno, ao microcrédito, às exportações, à implementação de estruturas logísticas e energéticas mais eficientes e à expansão do agronegócio e da agricultura familiar. 
Ainda no plano econômico, a gestão Lula se caracterizou pela estabilidade econômica, pelo aumento do PIB de 4,08\% de 2003-2010; o PIB per capita teve um incremento de 2,9\% no mesmo período; houve aumento da taxa de emprego - desde a sua posse, segundo dados oficiais, foram criados cerca de 4,2 milhões de postos de trabalho formais, uma média de 100.000 empregos ao mês. O aumento do salário mínimo foi de $\mathrm{R} \$ 200,00$ em 2002 para $\mathrm{R} \$ 510,00$ em 2010, tendo havido um incremento de 66,39\%. Houve também um incremento inédito na balança comercial, quase sempre superavitária e quebrando sucessivos recordes de exportação (BRASIL, 2019; BRASIL 2019a).

Em termos comparativos, em 2002 o governo FHC deixou aos cofres públicos US\$ 38 bilhões em reservas. Em 2017 esse montante foi de cerca de US\$ 368 bilhões, mudando seu status de devedor para credor internacional. O Valor de mercado das empresas ao final do governo Lula alcançou $70 \%$ de capitalização (BANCO MUNDIAL, 2018). O serviço da dívida total diminuiu de 67,92\% em 2003 para 18,37\% em 2010 (BANCO MUNDIAL, 2018). A taxa de Investimentos teve um aumento importante representando 16,85\% do PIB em 2003 para 21,80\% em 2010 (BANCO MUNDIAL, 2018), explicando assim, em parte, o melhor desempenho do PIB em relação ao governo FHC.

Tais dados apontam para um melhor desempenho do governo Lula do que o governo FHC. De fato, o crescimento econômico do país permitiu uma melhora das condições de vida da população de um modo geral. No entanto, estruturalmente o Brasil segue como um dos países mais desiguais do planeta e com uma sociedade marcada por fortes cesuras econômicas, sociais e raciais, embora tivesse melhorado sensivelmente seu nível de desigualdade socioeconômica nos últimos anos.

Lula da Silva faz sua sucessora nas eleições de 2010: a economista Dilma Rousseff, que fora Ministra de Minas e Energia e depois Ministra-chefe da Casa Civil de Lula. Foi um governo de perfil fortemente desenvolvimentista, marcado pelo recrudescimento político e fortalecimento da oposição conservadora.

Em meados do ano de 2013 ocorreram as chamadas jornadas de junho, grandes manifestações populares que brotavam em todo o país, ao modo das revoluções coloridas promovidas pelo soft power estadunidense na Ásia e na África (Korybko, 2018), tendo como reflexo uma forte queda de popularidade da 
mandatária brasileira. Neste mesmo ano, no mês de setembro, foram reveladas denúncias de que o governo dos Estados Unidos espionou o governo brasileiro e algumas de suas empresas mais importantes, especialmente a Petrobras.

Entre junho e julho de 2014 o Brasil sediou o Campeonato Mundial de Futebol com duas marcas de relevo: manifestações agressivas e machistas nos estádios contra Dilma Rousseff e a humilhante derrota da seleção brasileira nas semifinais para a Alemanha, com um histórico e retumbante $7 \times 1$. E isto não é um mero detalhe, sabendo-se que o futebol, no contexto brasileiro, sempre foi usado como uma ferramenta política.

Ainda em 2014 Dilma Rousseff se candidatou à reeleição, vencendo pela menor margem já registrada no país, em uma disputa voto a voto em que partidários do seu adversário, Aécio Neves, do PSDB, chegaram até a contar vitória durante a apuração. A reeleição por uma margem diminuta assinalou seu enfraquecimento político a um nível crítico, encorajando os adversários a sabotarem o orçamento federal (com a destinação de recursos financeiros exorbitantes para finalidades desnecessárias) e desestabilizarem o governo de forma constante e sistemática.

Neste período começa a ganhar corpo manifestações de ultradireita, ao mesmo tempo em que partes do aparato policial e jurídico-legal passam a assumir publicamente um posicionamento político de oposição à direita do governo, com auxílio da mídia corporativa (Messenberg, 2017). É neste momento que a Operação Lava Jato assume um grande protagonismo midiático, funcionando claramente como peça político-midiática.

Em dezembro de 2015, em meio a uma forte e generalizada pressão midiática, foi acolhido o pedido de Impeachment da presidenta. Em um processo extremamente espetacularizado Dilma Rousseff foi afastada pelo Congresso e depois cassada por uma manobra financeira corriqueira, sendo substituída em 2016 pelo vice, Michel Temer, que já estava articulado com a oposição de direita para assumir o posto, conforme posteriormente foi revelado em gravações em que políticos, empresários e magistrados conspiravam abertamente para a derrubada do governo.

No dia seguinte à assunção da presidência Temer torna legal o procedimento de crédito que foi a justificativa formal para a cassação da sua 
antecessora. O seu governo foi marcado por inúmeros escândalos de corrupção, com uma sangria jamais vista das contas públicas, inclusive para que ele próprio não fosse julgado por inúmeros crimes.

O Governo Temer deu andamento a uma série de contrarreformas que muito dificilmente seriam aprovadas pelas urnas, como a perda de direitos trabalhistas e previdenciários. Além da piora de todos os indicadores sociais, econômicos e ecológicos, registrou-se o avanço do desmatamento, 0 endividamento público recorde e o crescimento exponencial da pobreza e do desemprego. Poucas vezes na história o país se tornou tão conturbado social, política e economicamente do que no período de 2014 a 2018. Ao final deste ciclo ocorram novas eleições, marcadas por grande tensão, polarização e acirramento envolvendo inúmeros atos de violência, inclusive assassinatos.

Com forte ênfase na dimensão moralizadora e autoritária, o pleito foi vencido pelo ex-militar reformado Jair Bolsonaro. O candidato, que por 27 anos fora um deputado do "baixo clero" visto apenas como uma figura caricata e grotesca, e que moldara sua imagem pública com um apelo reacionário e revisionista da ditadura militar - não só minimizando como mesmo exaltando as torturas e mortes do período -, elegeu-se com uma pauta extremamente regressista, colocando-se enfaticamente contrário aos povos originários, negros, mulheres e direitos humanos.

Apesar das acusações comprovadas de financiamento irregular e uso de robôs em redes sociais e aplicativos móveis com finalidades de disseminar fake news em massa contra o adversário do partido de Lula, sua eleição não foi contestada. Ele foi apoiado por um arco político que uniu líderes religiosos, empresários do crime, partidos conservadores, a elite econômica nacional, milicianos e, obviamente, militares, que viriam a ter mais espaço no governo Bolsonaro do que jamais tiveram. Mais ainda do que tinham na própria ditadura militar de 1964.

\section{Os militares na democracia - 1985-2019}

Olhando em perspectiva o turbilhão econômico, social e político que tem sido o período da redemocratização, fica nítido que o país deixou de construir muitos alicerces institucionais que tornariam sua vida mais estável e saudável. 
Às incompletudes atuarial, educacional, político-institucional e jurídico-legal juntou-se a manutenção de privilégios jurídico-econômicos medievais e a consolidação de verdadeiras castas que se robusteceram ainda mais no pósditadura, como a magistratura, o segmento dos super-ricos - sempre imunes à justiça -, os clãs políticos e os militares, que jamais deixaram de ganhar privilégios.

Com efeito, foi apenas no governo FHC que o Brasil conquistou uma certa estabilidade econômica - embora com a custo altíssimo no período de transição para a população mais pobre - e, no governo Lula, uma combinação ímpar de crescimento econômico, redução das desigualdades e grandes avanços na área social, alimentava a crença de que o país tinha ajustado seu relógio civilizacional com a modernidade do ocidente industrial, mudado de patamar e, finalmente, havia ingressado, no século XXI, no seleto grupo dos "melhores" do Mundo.

$\mathrm{Na}$ antevéspera do golpe parlamentar que destituiu Dilma Rousseff, em 2016, discutia-se a destinação de $10 \%$ do PIB brasileiro para a educação. Mas, com duros atritos na política, uma forte campanha midiática contra o governo e o PT e uma economia errática, a euforia vivida no governo Lula começava a dar lugar à apreensão geral.

Apenas poucos anos antes havia uma sensação quase unânime da intelectualidade brasileira de que havíamos virado uma página da história e que finalmente o passado tinha ficado para trás. Mas a partir de 2014 o que parecia ser sólido começava a se desmanchar. E a sombra de um passado colonial, aristocrático e escravista dava sinais de engolfar o país novamente em um crepúsculo atávico e persistente. De modo sintomático, os segmentos mais conservadores voltavam a falar dos militares. E mais especificamente, de um "desconforto" deles a respeito dos rumos do país, que já era o transbordar de atritos importantes entre os militares e o governo federal (Abranches, 2021; Amorim, 2021).

Desde o fim do regime militar que os militares se esforçaram para demonstrar publicamente que estavam recolhidos à caserna. Havia um constrangimento em aparecer na cena política de maneira explicita e por parte da sociedade civil e da academia havia uma crença na robustez da nossa democracia. 
Na verdade, durante o período democrático os militares estiveram ativos na vida política, mas não de forma explicita. Pouco ou nada se ouvia falar sobre sua atuação. Entretanto - a despeito da sensação de que os militares estivessem contidos no período -, entre os governos Sarney, Collor, Itamar e FHC foramIhes auferidas altas prerrogativas:

As prerrogativas militares referem-se àquelas áreas onde, desafiados ou não, os militares como instituição, assumem ter adquirido o direito ou o privilégio, formal e informal, de governar tais áreas, de ter um papel em áreas extramilitares dentro do aparato de estado, ou até mesmo de estruturar o relacionamento entre estado e a sociedade política ou civil (Zaverucha, 1998, 2).

A narrativa sobre o período consolida essa sensação de isenção da caserna a respeito das atividades políticas. Mas é notável como durante todos esses governos os militares continuaram a ter ou, ainda mais, ampliar privilégios, atuar em áreas extramilitares, possuírem uma justiça própria e até mesmo controlar agencias de inteligência do Estado. Nem mesmo a criação do Ministério da Defesa, em 09 de junho de 1999, que extinguiu os ministérios militares independentes, condensando-os em um único ministério, foi capaz de retirar a tutela dos militares sobre o poder civil.

Com a ascensão do governo do Partido do Trabalhadores, em 2002, houve um temor em relação à atuação dos militares na política, que, a princípio, mostrou-se infundado. As prerrogativas militares seguiram vigentes, em especial no governo Lula. Como se os investimentos na área de defesa e a abertura para a participação dos militares em cargos importantes - como durante a feitura do Livro Branco da Defesa, criado em 2010 e lançado em 2012 - fosse suficiente para manter os militares dentro da caserna. Mas a crença dos civis no respeito à democracia por parte dos militares mostrou-se um erro.

$\mathrm{Na}$ realidade, as prerrogativas militares foram mais atendidas durante $\mathrm{o}$ governo Lula e isso amainou os ânimos. Porém, não se sustentou após a implementação de um processo que buscava revisitar o passado ditatorial do país, instituindo uma justiça restaurativa. De fato, o golpe de 2016 que tirou Dilma Rousseff do Planalto foi articulado também pelos militares (Leirner, 2021). De acordo com o General Villas Bôas, alguns momentos políticos protagonizados pelos governos do PT foram fundamentais para as ações militares futuras: 
Os governos do PT, a despeito de nos terem proporcionado algum alívio orçamentário, foram aos poucos desencantando aqueles em quem despertaram algum otimismo inicial. Os casos gravíssimos de corrupção, a progressiva deterioração da economia, a falta de visão de Estado, a Comissão da Verdade e a autocrítica do PT, documento elaborado em maio de 2016, pelo diretório de São Paulo, no qual reconhecem como erros não terem alterado os currículos das escolas militares, bem como por não terem interferido nas promoções provocaram um sentimento não simpático à esquerda em geral (VILLAS-BÔAS, In: CASTRO, 2021, 164).

É preciso ressaltar que o governo do presidente Lula foi tido como mais favorável. Não havia, naquele momento, indícios de insatisfação militar, como corrobora o excerto da entrevista do general Villas Bôas:

O presidente Lula adotou medidas positivas e, até mesmo, inovadoras. Reverteu a tendência declinante dos orçamentos de defesa e adquiriu mais de 14 mil viaturas, para o Exército que andava a pé. A Estratégia Nacional de Defesa (END) foi um marco, em razão dos desdobramentos que provocou [...] (CASTRO, p. 179).

Os investimentos do PT em defesa não deixam de ser reconhecidos, porém alguns pontos colocam-se como determinantes para essa virada à direita, e dentre eles encontramos a instituição da Comissão Nacional da Verdade (CNV), que foi um momento importante, apesar de ter se constituído com um papel bastante restrito, tendo em vista que a Justiça de Transição foi tardia no Brasil e não coube à CNV o papel de Justiça Punitiva, uma vez que a Lei No 6.683, conhecida como Lei da Anistia, seguiu em vigor. A CNV foi, portanto, um resgate da memória, da verdade e da justiça, que compõem o direito social (ATASSIO; AUGUSTINHO, 2021).

Todavia, na visão dos militares, a Comissão foi um ato "revanchista", onde a esquerda pretendia impor sua narrativa. Conforme aponta o Gen. Villas Bôas em seu livro de entrevistas, "integrada somente por representantes de esquerda, no nosso entender, perdeu a legitimidade" e segue dizendo que a Comissão tinha, portanto, "claro viés revanchista, criando em nós, embora não de forma intensa, uma espécie de 'revanchismo ao contrário'." (CASTRO, 2021, 158).

Fica evidente que, mesmo mantendo as prerrogativas militares, o governo Dilma Rousseff não foi avaliado pela caserna com a mesma positividade que o governo Lula. Segundo o general Villas Bôas, a CNV marcou essa atitude dos 
militares com relação à Dilma, pois sua instituição foi sentida como uma traição do governo: "Foi uma facada nas costas, mesmo considerando que foi decorrência de antigos compromissos assumidos pela presidente Dilma" (idem, p. 179).

Assim, não obstante a tentativa de legitimação do discurso que coloca os militares como defensores da Constituição e só atuantes dentro desta esfera, encontramos em vários autores indícios fortes da insatisfação dos quartéis (com forte influência dos reformados do Clube Militar) com o ultimo governo do PT, sob a figura de Dilma Rousseff, que deu suporte e musculatura ao discurso do retorno dos militares ao centro do poder que já existia como um projeto político anterior ao governo Bolsonaro (Leiner, 2020; Castro, 2021; Martins Filho, 2021).

Os militares estiveram presentes em decisões políticas importantes, garantidos pela Constituição de 1988. Nem mesmo a Constituição cidadã eliminou a existência de poderes nas mãos das Forças Armadas, como um resquício ditatorial. Zaverucha (1998) listou 17 prerrogativas militares existentes no âmbito de governos civis. Tais prerrogativas não foram suspensas nos governos do Partido dos Trabalhadores. Havendo, inclusive, participação militar maciça na construção da Estratégia Nacional de Defesa (END).

Dentre estas prerrogativas, a que garante maior poder aos militares é o próprio Artigo 142 da Constituição Federal, que coloca as Força Armadas como responsável por garantir os poderes constitucionais, a lei e a ordem. As implicações do Artigo 142 englobam a possibilidade de interpretações diversas especialmente par ao conceito de ordem, que pode ser diretamente influenciado por questões ideológicas, sendo compreendido de acordo com o interesse do momento.

Em uma sociedade marcada pelas intervenções militares e na qual perdura o imaginário interno da e na instituição como guardiã da república, da moral e da "democracia", brechas interpretativas podem ser utilizadas para justificar e amparar intervenções para a contenção dos avanços democráticos (Castro, 2002; Barbosa, 2018). Com efeito, a democracia brasileira é tão conservadora com os assuntos relacionados aos interesses militares que não há sequer o sentimento de descontentamento que impulsione os militares a 
contestarem os governos civis (Linz e Stepan, 1996). Isso só ocorrerá anos depois, com a ascensão de Dilma Rousseff à presidência.

É notável, por exemplo, que o processo de anistia no Brasil tenha sido marcado pela tentativa de reescrever o passado, isentando agressores responsabilidades perante os feitos durante a Ditadura. O processo de anistia total e irrestrita permitiu o retorno do convívio no Brasil de agentes que haviam participado de todo o processo arbitrário de prisões e suas consequências ilegais, como tortura e desaparecimentos políticos, sob a égide do governo brasileiro. Não houve no Brasil a justiça de transição. Essa só será realizada muito tardiamente, não obstante os clamores das famílias das vítimas. E que terá como consequência o sequestro do mandato de um presidente da república.

Durante os governos civis, com ênfase para os governos de FHC, Lula e Dilma, o artigo 142 foi utilizado para mobilizar as Forças Armadas em atividades de polícia através das atividades de Garantia da Lei e da Ordem (GLO). Essas ações se tornaram prioridade dos militares, bem como a participação na formulação da Estratégia Nacional de Defesa.

Com o fim da Guerra Fria e do inimigo comunista, as GLO tiveram o condão de empoderar os militares brasileiros na reformulação de suas atividades, recriando o inimigo interno na figura da violência e do tráfico de drogas, ambos problemas de segurança pública e não defesa nacional.

E aqui se tem outra prerrogativa militar exótica para uma democracia, cuja repercussão jurídico-legal é realmente impactante: a possibilidade quase nula de militares da ativa serem julgados por tribunais comuns, pois possuem sistema jurídico próprio, a justiça militar. O agravo dessa prerrogativa ocorreu no governo de Michel Temer, em 2017, quando a Lei 13.491/2017 alterou dispositivos do Código Militar e delegou apenas para a Justiça Militar a competência de investigação e julgamento de integrantes das Forças Armadas que cometerem crimes dolosos que atentem contra a vida de civis. Assim, militares que atuam em ações do tipo GLO passaram a ser investigados e julgados pelos próprios pares, retirando da sociedade civil o controle da atividade militar, além de criar uma distinção de tratamento entre civis e militares.

O envio de tropas nas denominadas Missões de Paz da ONU também foi uma constante durante esses governos e garantiu autonomia de atuação das 
Forças Armadas em situações de poder. As Missões já figuravam como atividades militares constitucionais desde 1948, porém foram intensificadas e publicizadas a partir de meados da década de 1990.

A Minustah, Missão das Nações Unidas para Estabilização no Haiti, que se deu entre 2004 e 2017, deslocou para o Haiti, neste lapso de 13 anos, cerca de 37 mil oficiais das Forças Armadas brasileiras. O Brasil foi o país líder da missão e atuou, inclusive, como apoio à Polícia Nacional do Haiti, além de desempenhar papel junto à Polícia da ONU (UNPOL) (HAMANN; RAMIRES TEIXEIRA, 2017).

Conhecidos como Turma do Haiti, os militares que comandaram as tropas na missão de pacificação e reconstrução daquele país se consagraram no Brasil, ganhando prestigio dentro e fora dos quartéis. Não resta dúvida que a Minustah se tornou um importante celeiro de lideranças para os militares que futuramente atuaram no governo Bolsonaro. Conforme lista Motoryn, 2021:

O general Augusto Heleno, que foi o primeiro comandante da missão, ainda em 2004, se integrou à campanha presidencial de Jair Bolsonaro em 2018, está no governo desde o primeiro momento e hoje ocupa o cargo de ministro-chefe do Gabinete de Segurança Institucional (GSI).

O general Santos Cruz, comandante no Haiti entre 2007 e 2009 ocupou o cargo de ministro-chefe da Secretaria de Governo da Presidência da República no primeiro ano de governo e foi demitido após atritos com a família do presidente e seguidores do "filósofo" Olavo de Carvalho, espécie de guru dos Bolsonaros.

Santos Cruz foi substituído no cargo pelo general Luiz Eduardo Ramos, que comandou as tropas brasileiras no Haiti entre 2011 e 2012. O general Floriano Peixoto, que comandou a Minustah entre 2009 e 2010 foi ministrochefe da Secretaria-Geral da Presidência da República de Bolsonaro e assumiu em seguida a presidência da Empresa Brasileira de Correios e Telégrafos (ECT) que enfrentou uma greve histórica este ano.

O general Edson Leal Pujol, que comandou a Minustah entre 2013 e 2014 é comandante do Exército brasileiro desde 2019 [substituído por Paulo Sérgio Nogueira de Oliveira em 31 de março de 2021]. O general Ajax Pinheiro que comandou a missão no Haiti de 2015 até a retirada total das tropas brasileiras em 15 de outubro de 2017 foi escolhido por Dias Toffoli, então presidente do Supremo Tribunal Federal (STF), como assessor especial em novembro de $2018 \quad$ (Disponível em $<$ https://www.brasildefato.com.br/2021/07/07/crise-no-haiti-tem-digital-degenerais-bolsonaristas-saiba-quais-ministros-atuaram-no-pais>. Acessado em 08 Ago. 2021).

Vale assinalar também que na redemocratização os governos civis não interferiram em postos-chave de atuação militar nas instâncias de poder. Além 
disto, permaneceu intensa a participação de militares em gabinetes governamentais e nas atividades de inteligência. As consequências são visíveis atualmente.

\section{Considerações finais}

Durante a Nova República, enquanto que a vida civil foi marcada por constantes intempéries políticas, econômicas e sociais, no campo militar se dava um conjunto de ações de forma silenciosa e progressiva em procedimentos contínuos de manutenção e ampliação de privilégios que se deram nos bastidores e dentro da legalidade constitucional. Tanto assim que prerrogativas militares jamais foram derrubadas. Ao contrário. Os militares se fortaleceram com as GLO e especialmente com a MINUSTAH, até chegarem ao ponto de atuação direta no governo Bolsonaro.

Dizendo de outro modo, no lapso temporal de 1985 a 2018, que vai do fim da ditadura de 64 até a eleição de Bolsonaro - que inaugurará um novo momento marcado por ataques sistemáticos aos pilares democráticos, institucionais e civilizacionais, e pelo aparelhamento sem precedentes do Estado pelos militares -, a caserna atuou como um verdadeiro tutor da democracia (e dos governos civis) e nos raros momentos em que foi confrontada operou abertamente para derrubar o poder constituído, reforçando a ideia de que não só os militares se colocam como os senhores da república, outorgando a si mesmos o direito de sustá-la, como também - contrariando o senso comum - jamais deixaram de fazer política, a seu modo. Estas são, em linhas gerais, as principais premissas deste texto.

Entende-se que este é um delineamento inicial de um esforço que seguirá no sentido de aprofundar questões importantes para um melhor entendimento do Brasil na dimensão dos seus arranjos sócio-políticos, no contexto de uma sociedade em vias de consolidação de seus tardios e ainda débeis pilares institucionais e civilizacionais, hoje abalados pela crise sem precedentes provocada pela figura do Presidente da República Jair Bolsonaro, com suas ameaças diretas e diárias de deflagrar um golpe de estado com apoio dos militares. E embora esta remissão final não se constitua no eixo central do texto, 
Universidade Federal Fluminense

Instituto de Estudos Estratégicos

ela é importante para assinalar a dimensão processual e consequencial da arquitetura do poder civil no Brasil que se apresenta mais do que nunca ambígua e carente de firmeza.

\section{Referências}

ABRANCHES, Sérgio. A crise militar do governo Dilma. Sul 21. Disponível em: https://sul21.com.br/opiniao/2012/03/a-crise-militar-do-governo-dilma/. Acesso em 06 de agosto de 2021.

AMORIM, Celso. Nosso erro foi ter tido condescendência. Entrevista. DW Brasil. Disponível em: https://www.dw.com/pt-br/nosso-erro-foi-ter-tido-condescendência-dizcelso-amorim/a-57081125. Acesso em 06 de agosto de 2021.

ATASSIO, Aline Prado. A Batalha pela memória: os militares e o golpe de 1964. Dissertação. Mestrado. PPGSCo/UFSCar, 2007.

ATASSIO, Aline Prado; AUGUSTINHO, Aline Michele Nascimento. O Lugar da Democracia nos Processos de Revisionismo Conservador: Memória e Política. Democracia Brasileira em Questão: Enredos, Conflitos e Perspectivas. 1ed.Caruaru:Mnemosine, 2020, v. 1, p. 89-104.

BARBOSA, Jefferson Rodrigues et al (orgs.). Militares e Política no Brasil. São Paulo: Expressão Popular, 2018.

BARROS DE CASTRO, A.; SOUZA, F. A economia brasileira em marcha forçada. Rio de Janeiro: Paz e Terra. 1985.

BANCO MUNDIAL. (2018) Worldbank Indicator. Disponível em: https://data.worldbank.org/indicator/ST.INT.ARVL.

BRASIL. (2019). Banco Central do Brasil. Indicadores econômicos. Disponível em: https://www.bcb.gov.br/estatisticas/indicadoresconsolidados. Acesso em 20 jun 2019.

BRASIL. (2019a). IPEA. Instituto de Pesquisas Econômicas Aplicadas. Disponível em: http://www.ipeadata.gov.br/Default.aspx. Acesso em 10 jun 2019.

CANO, W. Desconcentração produtiva regional do Brasil: 1970-2005. São Paulo: UNESP. 2008.

Ensaios sobre a crise urbana no Brasil. Campinas: UNICAMP. 2011.

CARVALHO, José Murilo de. Forças Armadas e Política no Brasil. São Paulo: Todavia Editora, 20005.

A formação das almas: o imaginário da República no Brasil. São Paulo: Companhia das Letras, 2007.

CASTRO, Celso. A Invenção do Exército Brasileiro. Rio de Janeiro: Jorge Zahar, 2002.

CASTRO, Celso (org.). General Villas Bôas: conversa com o comandante. Rio de Janeiro: FGV Editora, 2021. 
DINIZ, E. Reforma do Estado e governabilidade no Brasil. Brasília: UNB. 1997.

GALEANO, E. (2004) Futebol ao sol e à sombra. Porto Alegre: L\&PM.

GONÇALVES, R. Desenvolvimento às avessas. São Paulo: LTC. 2013.

HAMANN, Eduarda Passarelli e RAMIRES TEIXEIRA, Carlos Augusto. A participação do

Brasil na MINUSTAH (2004-2017): percepções, lições e práticas relevantes para futuras missões. Rio de Janeiro: Instituto Igaraé, 2017.

KORYBKO, Andrew. Guerras Híbridas: das revoluções coloridas aos golpes. São Paulo: Expressão Popular, 2018.

LEIRNER, Piero. O Brasil no espectro de uma guerra híbrida: militares, operações psicológicas e política em uma perspectiva etnográfica. São Paulo: Alameda, 2020.

LINZ, Juan J.; STEPAN, Alfred. Problems of Democratic Transition and Consolidation: Southern Europe, South America and PostCommunist Europe. Baltimore and London: Johns Hopkins University Press, 1996.

LOPES, P. M. Formação da dívida externa brasileira como consequência do sistema financeiro desregulamentado, 1969-1982. Dissertação de Mestrado apresentada ao Programa de Pós-graduação em Economia. Universidade Federal do Rio Grande do Sul. 1998.

MARTINS FILHO, João Roberto (Org). Os militares e a crise brasileira. São Paulo: Alameda, 2021.

MESSENBERG, Débora. A direita que saiu do armário: a cosmovisão dos formadores de opinião dos manifestantes de direita brasileiros. Sociedade e Estado, v. 32, n. 3, p. 621-648, $2017 . \quad$ Disponível em <http://www.scielo.br/scielo.php?script=sci_arttext\&pid=S0102-

69922017000300621\&lng=en\&nrm=iso $>$. Acessado em 24

Mar. 2021. https://doi.org/10.1590/s0102-69922017.3203004.

MOTORYN, Paulo. Crise no Haiti tem digital de generais bolsonaristas. Brasil de Fato. Disponível em <https://www.brasildefato.com.br/2021/07/07/crise-no-haiti-tem-digitalde-generais-bolsonaristas-saiba-quais-ministros-atuaram-no-pais $>$. Acessado em 08 Ago. 2021.

MOUFFE, Chantal. O regresso do político. Lisboa: Gradiva, 1996

PARKER, P. Brazil and the quiet intervention, 1964. Austin: Texas University Press. 2014.

LEIRNER, Piero Camargo. "Projeto Bolsonaro Presidente foi construção de generais" [entrevista concedida a] João Pedro Soares. DW Notícias, 18/02/2021. Disponível em: https://p.dw.com/p/3pY7U. Acesso em 03/08/2021.

SINGER, A. (2010). A segunda alma do partido dos trabalhadores. Novos estudos CEBRAP, (88), 89-111. https://dx.doi.org/10.1590/S0101-33002010000300006 
ZAVERUCHA, Jorge. Sarney, Collor, Itamar, FHC e as Prerrogativas Militares (19851998). Paper. Latin American Studies Association, Chicago, Illinois, September 24-26, 1998. Disponível em: http://biblioteca.clacso.edu.ar/ar/libros/lasa98/Zaverucha.pdf. Acesso em 06 de agosto de 2021. 